$=$

\title{
Bulgaristan Türklerini Komünizme Kazandırma Sürecinde Türk Coğrafyası Propagandasi*
}

\author{
Turkish Geography Propaganda in the Process of Bringing Bulgarian Turks Into \\ Communism
}

\author{
Süleyman KÖKSAL ${ }^{* *}$
}

\begin{abstract}
ÖZET
Türk nüfusunun en yoğun olduğu Balkan ülkesi Bulgaristan'dır. İkinci Dünya Savaşının galibi Sovyet Rus askeri 9 Eylül 1944 tarihinde Bulgaristan'a girdi. Bu tarihte başlayan komünist rejimin iktidarı 1989 yılı sonuna kadar sürdü. Altyapısı önceden oluşturulan komünist iktidar tarafından Türk azınlığın toplumsal yapısında başta eğitim olmak üzere iyileştirme planları yapıldı ve uygulamaya konuldu. Türklerin eğitimle Bulgar toplumu içinde asimile edileceği hesaplandı. Bulgaristan Türklerine yönelik yapılan Türkçe yayınlarla, propagandistlerle Türkler arasında komünizme sempatiyle yaklaşan bir kesim oluşturulmak istendi ve Türklerin kültürel değerleri yok edilmeye çalışıldı. Bulgaristan Türklerini komünizme kazandırma sürecinde Bulgar toplumu içinde asimile edilmesi, sürgün veya göç ettirilme düşüncesi vardı. Sovyetler Birliği hâkimiyetindeki Türk Coğrafyası bu faaliyetler çerçevesinde propaganda amaçlı kullanılmıştır. Bulgaristan Komünist Partisi'nin Türkçe Servisi Sovyetler Birliği sınırları içindeki Türk Coğrafyası'ndan gelişmişlik, üretim, barış ve mutluluk haberlerini sosyalizm adı altında yansıtmıştır. Sovyet Yönetimi tarafından yapılan hizmetler sanki karşılıksız yapılmıştır. Emperyalizm, Türkiye ve Türkiye Türklerine karşı ise olumsuz bir yaklaşım sergilenmiştir.
\end{abstract}

Anahtar Kelimeler: Bulgaristan, Türk, Propaganda, Türk Coğrafyası.

\begin{abstract}
Bulgaria is the Balkan country with the highest number of Turks. Soviet Russian soldier, winner of World War 2, entered Bulgaria on September 9, 1944. The power of the communist regime that started on this date continued until the end of 1989. Improvement plans, especially education, were made and put into practice in the social structure of the Turkish minority by the communist government, whose infrastructure was previously created. It was thought that the Turks would be assimilated into the Bulgarian society by education. Through the Turkish publications and propagandists for the Turks of Bulgaria, it was aimed to create a group among Turks who sympathized with communism. The cultural values of the Turks were tried to be destroyed. In the process of bringing Bulgarian Turks into Communism, there was the idea of assimilating Turks within Bulgarian society, forcing exile or immigration. Turkish Geography under the Soviet Union was used for propaganda within the framework of these thoughts. Turkish Service of the Bulgarian Communist Party gave news of development, production, peace and happiness from the Turkish Geography within the borders of the Soviet Union. These news were reflected as activities achieved through socialism. The Soviet Administration made these services as if they were unrequited. Imperialism, Turkey and Turks in Turkey are shown in a negative way.
\end{abstract}

Keywords: Bulgaria, Turk, Propaganda, Turkish Geography.

\section{GíRiş}

\footnotetext{
* 27-29 Haziran 2019 tarihleri arasında İstanbul'da düzenlenen V. TURKCESS Eğitim ve Sosyal Bilimler Kongresi’nde özet bildiri olarak sunulmuştur.

*** Dr., Karadeniz Teknik Üniversitesi, Yabanc1 Diller YO, Trabzon, Türkiye. ORCID 0000-0002-0514-9256. skoksal@ktu.edu.tr
} 
Adriyatik'ten Çin Seddine baktığımızda Türk Coğrafyası'nın büyük bölümü doğu bloku ülkelerinin özellikle Sovyetler Birliği'nin sınırları içindedir. Osmanlı Devletinin dağılmasıyla Balkanlar'da ortaya çıkan devletlerde önemli sayıda Türk nüfusunun olması bölgedeki devletlerin Türklere karşı politikalar üretmesine sebep olur. Bu ülkelerden biri de Bulgaristan'dır. Bu çalışma başlıktan da anlaşılacağ1 gibi Bulgaristan Türklerinin komünizm döneminde (1944-1989) asimile edilmeye çalışılırken uygulanan politikalardan birinin incelenmesidir. Türklerin baskı altında asimile edilmeye çalışıldığı veya Bulgaristan'dan Türkiye'ye göçe zorlandığı görülmektedir. Bir kısım Türklerin de desteklediği yönetim Türkleri rejime intibak ettirmeye çalışır. Bulgaristan Komünist Partisi (BKP)'nin Türkçe Servisi ciddi bir çalışma içine girer. BKP yayınlarında bu plan dâhilinde propaganda yazıları ele alınır. Türk Coğrafyası'nın Sovyetler Birliği ve sosyalizmle birlikte refaha kavuştuğu, mutluluğu yakaladığı algısı oluşturulmaktadır. Böylece Türkler kolaylıkla Bulgar toplumu içinde yok edilecektir. Komünist rejimin ilk yıllarında nispeten bask1 görülmemektedir. İlerleyen yıllarda ise şiddetini artıran bir baskı vardır. Özellikle 1954 yılında BKP Sekreteri olan Todor Jivkov döneminde başlayan baskılar 1989 yılına kadar sürer. Çalışmamız olayların geçtiği ve kaynaklara kolay ulaşılması düşüncesinden hareketle Bulgaristan'da alan araştırması ve Bulgaristan'ın farklı kütüphanelerindeki komünizm dönemindeki yayınların incelenmeleri şeklinde olmuştur. Kullanılan kaynakların önemli bir kısmı BKP'nin yayınları olan Iş̧ı, Yeni Işık, Halk Gençliği gazeteleri ile Yeni Hayat, dergisidir. Ayrıca Bulgaristan Türk aydınlarının ve Türkiye'den Bulgaristan'a kaçan komünist düşünceye sahip mülteci Türklerin yazılarından da faydalanılmıştır. İncelemeler sonucu 1945 yılından günümüze kadar olan tarihleri kapsayan yayınlara ulaşılmıştır. Edinilen bilgilerin önemli bir bölümünün BKP'nin yayınları olması o dönemin zihniyetini yansıttığı için araştırmada kaynak olarak kullanılmıştır. Bu belgeler ve edinilen izlenimler neticesinde Bulgaristan Türklerinin asimilasyon politikalarına maruz kaldıkları ve baskı gördükleri tespit edilmiştir. Nitekim bu baskılar 1989 yılı ortalarında yüzbinlerce Bulgaristan Türkü'nün Türkiye'ye göçüne sebep olmuştur.

\section{Komünist İktidar, Politikaları ve Propagandaları}

Dimitır Blagoyev ve Nikola Trayçev Bulgaristan sosyalistlerinin ilk akla gelen fikir öncüleri olarak bilinir. Blagoev Makedonya'da doğdu. 1878 yılında gittiği Rusya'da devrimcilerin safında yer aldı. Çarlık güçleri tarafından tutuklanarak sınır dışı edildi. Bulgaristan'a döndü ve işçileri örgütleyerek sosyalizm propagandalarına başladı (Bulgaristan Komunist, 1956: 1). Blagoev Rusya'da iken Raboçiy (işçi) gazetesini çıkarmıştı. Balkanların en önemli Marksist'i olarak biliniyordu. Türklerle Bulgarlar arasındaki mücadelelere karşı çıkmış, Türklere yapılan zorbalıkları protesto etmiştir (Partinin Kurucusu, 1976: 1). Nikola Trayçev ise 1908 yılında İstanbul'da eski kâğıt ticareti yapan anonim şirket sahibiydi. Rus ve Türk sosyalistleri ile irtibatlıydı. Sofya, Filibe, Makedonya ve İstanbul'da faaliyetlerde bulundu. 1921 yılında İstanbul'da birkaç ay tutuklu kaldı ve sonrasında Sovyetler Birliği'ne gitti. Odesa, Tiflis ve Batum'da faaliyetlerini sürdürdü (Vekov, 1980: 2, 3). Bu yıllarda Bulgaristan Türkleri arasında sosyalist saflarda mücadele edenlere destek verenler vard1. Bunlar 1919'dan 1923'e kadar Ziya adlı Türkçe bir gazete yayınlamışlardır (Yalımov, 2000: 152155).

Bazen açık bazen gizli olarak faaliyetlerini sürdüren komünistler dikkat çekici bir etki alanı oluşturmuşlard1. (BCA, 1933: 30-10-0-0_241-627-19_) Moskova ile irtibat halindeydiler. Ruslar Balkanlarda oldukça faaldi. Balkanlar büyük devletlerin mücadele alanı olmuştu. Bulgaristan 2. Dünya Savaşı öncesinde Nazi Almanya'sının adeta bölgedeki jandarması konumundaydı. Nazi ordusunun desteğiyle Bulgar birlikleri Batı Trakya, Makedonya ve Sirbistan'a girdi (Mateev, 1976: 28). Bulgaristan ekonomisi 2. Dünya Savaşına doğru tamamen Almanya'ya bağlanmıştı. Dış ticaretinin yüzde 90'1 Almanya ile yapılıyordu (Todorova, vd. 2011: 135).

Bulgaristan'da merkez sol 2. Dünya Savaşı öncesinde biçimlenmeye başladı. Bu gruptakiler Bulgaristan ile Sovyetler Birliği'nin menfaatlerinin çakıştığını ve Bulgaristan'ın dış politikasında Sovyetler Birliği ile işbirliği yapılmasını istiyorlardı. Merkez sol komünistlerle birlikte ortak 
paydalarda buluşarak Vatan Cephesi adı altında kendilerini gösterdiler (Mateev, 1976: 27). Sovyetlerin savaştan galip çıkmasıyla komünistler Bulgaristan'da 9 Eylül 1944'de iktidarı ele geçirdi ve kısa zaman içinde 2 bin 138 kişi idam edildi (Gürün, 1983: 215). Bulgaristan artık komünist partisinin hâkimiyetinde ve başını Sovyetler Birliğinin çektiği doğu bloku üyesi bir ülke olmuştur. Soğuk Savaş Dönemi 2. Dünya Savaşı’nın bitmesiyle başlayan ve mazlum milletlerin tarihinde unutulmaz zalimliklerin yer aldığ 1 bir döneme adını verecektir.

Yönetime gelen komünistler ülkedeki her kesime sıcak mesajlar verdi. Karşılarında muhalif bir kesim istemiyorlardı. En önemli kesim Türklerdi. Yönetimin Türklere yönelik bazı politikaları dikkat çekmektedir. Bunlar, Türkleri asimile etmek için dil, din ve geleneksel hayatlarından vazgeçmelerine yönelik propagandalar ve dış politika bağlamında kullanılan, Türkiye'de halkın eğitimsiz, sağlıksı, geçim kaygısı içinde, teknolojiden yoksun bir hayat sürdürdükleri fakat yöneticilerinin savaş yanlısı bir tutum izledikleri algısıdır.

Komünizmle birlikte eğitimde bir hamle yapılması planlandı. Bulgaristan'da okur-yazar oranı yüksekti. Fakat Türk ve Çingenelerde bu oran yüzde 10'lardaydı. Çingenelerin yaşam tarzı ve Türklerin dinî anlayışı bu oranı yükseltmişti (Cicovska, 1976: 259). Türklerin eğitim seviyesinin düşük olması; sürekli göç ettirilen Türklerin önemli bir kesiminin eğitimli olmasından kaynaklanıyordu. Politika ve propagandalarda komünist partisinin Türkçe servisi ciddi bir faaliyet içine girmiştir. Bu serviste Bulgarlar, Bulgaristan Türkleri ve Türkiye'den Bulgaristan'a kaçan komünist mülteci Türkler vardır.

Komünizmin ilk y1llarında (özellikle 1950'den itibaren) eğitimde ciddi bir ilerleme görülmektedir. Türk Pedagoji okulları açılmıştır. Türkçe okullarla ilgili müfettiş kadroları tahsis edilmiştir. 1957 yılına gelindiğinde bin 155 ilk ve ortaokulda 105 bin öğrenci Türkçe eğitim alıyordu. Bulgar okullarında okuyan Türk öğrencilerinin yanı sıra yarı yüksek ve yükseköğretim mezunu Türkler de vardı. Türkler arasında aydın bir kesim oluşmuştu. Bazı Türkler de Sovyetler Birliği'ne eğitim alması için gönderilmektedir (Tatarl1, 2009: 234). Moskova eğitim anlamında bir merkez konumunda ve doğu bloku yöneticileri adeta burada belirlenmektedir. Bakü ve Sofya'da da yaşayan Zekeriya Sertel Avrupa'da Sorbonne ve Amerika'da Columbia üniversitelerinde okumuştur. Özel olarak yaptığı bir gezide Moskova'da üniversiteyi görünce adeta büyülenir ve Sorbonne ile Columbia gözünde küçülüverir. 1 milyon 200 bin cilt kitaba sahip bir kütüphane, doğu bloku ülkelerinden gelen ögrenciler, tek kişilik odalı yurtlar vardır. Paris, Amerika ve Türkiye'de bu şartlarda öğrenci yoktur. Moskova Üniversitesi SSCB'nin ileri cemiyet kadrolarını hazırlamaktadır. Bütün dünya buradan aydınlanacaktır (Sertel, 1954: 7, 16, 17).

Türklerin eğitimdeki gelişmeleri komünist yöneticileri endişelendirdi. Eğitimli Türkler haklarını sorgulamaya başlamışlardı. Böylece 1959 yılından itibaren Türk liselerinin bir kısmı kapatılmaya, bir kısmı da genel devlet liseleriyle birleştirilmeye başlandı. Türkçe dersleri azaltılmış ve sonra da yasaklanmıştır (Tatarlı, 2003: 62). BKP Bulgaristan Türklerinin diline de müdahale etmiş ve Bulgaristan'ın sadece bir yöresine ait bir ağızla konuşulup yazılmasına çalışmıştır. Ancak kaderin cilvesi mülteci Türk komünistleri bu anlamda Türkiye Türkçesi adına gayret göstermişlerdir. ${ }^{1}$ Dile müdahale de benzer bir durum Sovyet Rusya'da da görülmektedir. Tatarca'nın milliyetçi Tatarların ithal ettiği Arap, Fars ve Türk kelimelerinden kurtarılacağı ve gelişeceği savunulmuştur. Tatar okullarındaki öğrenci sayısı azaltılmış, bu da komünist dilinde halkların birbirlerine yakınlaşmalarının doğal seyri olarak açıklanmıştır. Aslında bu faaliyetler Sovyetler Birliği Komünist Partisi (SBKP)'nin Tatarları Slavlaştırma ideolojisinin bir ürünüydü (Devletşin, 1981: 367, 492).

Türklerin Balkanlarda varlık sebebi olan din bölgede farklı etnik kökene mensup kesimi kültürel anlamda Türklüğe kazandırmıştır. $\mathrm{Bu}$ coğrafyada Müslüman ve Türklük aynı anlamda kullanılmaktadır. Komünizm döneminin ilk yıllarında İslam aleyhine açıktan bir cephe alınmamıştır. BKP'nin gazete manşetlerinde Ramazan ve Kurban Bayramı kutlamaları vardır. Din adamlarının görüşlerine yer verilmektedir (Kurban, 1947: 1; Ramazan, 1948: 1). Türklerin haklarını sorgulamaları

${ }^{1}$ Ayrıntılı bilgi için bkz. Mehmet Akpınar ve Süleyman Köksal, Türkiyeli Komünistlerin Bulgaristan Türklerinin Dil ve Eğitimindeki Etkisi. 
dile müdahale ile birlikte dinsizlik propagandasını da başlatmıştır. Bir yandan Türkçe'nin yok edilmeye çalışılması bir yandan da dinsizlik propagandaları ile yayınlarda İslam, Kur'an, Peygamberler (Petrof, 1955: 16, 17), din adamları, dinî vecibeler (Bilalof, 1959: 2) aleyhinde yazılara başlanmıştır.

Türklerin geleneksel yaşantılarında kısıtlamalara hatta yasaklamalara da gidilmiştir. Türk kadınlarının geleneksel kıyafetleri terk ederek modern kıyafetleri tercih etmeleri, her alanda başarılarını artıracaktır propagandaları yapılmıştır (Dün Fereceli, 1961: 2). Türk gençleri içki içmeye yönlendirilmiş, Bulgar gençlerine ise yasaklanmıştır (Cambazov, 2005: 48, 49). Türklerin domuz beslemesi teşvik edilmiştir (Tatarova, 1962: 5).

İç politikada bu uygulamalar hayata geçirilmiş dış politikada ise Türkiye, Türkiye Türkleri, yine iç politika malzemesi olarak kullanılmıştır. BKP propagandalarında Türkiye'nin devamlı savaşa hazırlandığı algısı yaratılmaktadır. Türkiye 1948 yılı bütçesinin üçte ikisini askeri masraflara ayırırken bedelini de 20 çeşit vergiyle Türk emekçileri ödemektedir. Türkiye, bölgeyi savaş alanına çevirecektir (Türkiyenin Askerileştirilmesi, 1948: 3). ${ }^{2}$ Türkiye'de Sovyet karşıtı hükümet, emperyalist Amerika için devleti militarize etmektedir (Türkiyenin Mali, 1948: 1).

1950'de iktidara gelen Demokrat Parti (DP) batı yanlısı bir dış politikayı tercih etmiş ve Kore savaşına asker göndermiştir. Bu yüzden Türkiye'ye karşı Bulgaristan'ın Kırcali ve Haskova gibi Türklerin yoğun oldukları bölgelerinde gösteriler yapılıyordu (Kore, 1952: 1). Türkiye'nin Kore'ye askerî desteği ve arkasından NATO'ya girmesi Sovyetler'in tepkisini çekmiş ve Türkiye tehdit edilmiştir. Çünkü komünizm propagandası yapılamayacak bir Türkiye oluşmaktadır (Saray, 2000: 138). Türkiye'nin NATO'ya girmesiyle 3 Kasım 1951 tarihinde Sovyetler bir deklarasyon sunmuş (Sovyet Hükümetinin, 1951: 4), 22 Şubat 1952 tarihinde de Bulgaristan bir nota vererek doğrudan Bulgaristan'a yönelik bir tehdit olduğunu bildirmiştir (Bulgaristan Halk, 1952: 4). Mülteci Türk Halis Okan da Türkiye'nin 2. Dünya Savaşı'ndan sonra Amerika'nın askeri üssü ve hammadde kaynağ1 yapıldığını, bütçesini askeri masraflara ayırdığını öne sürmüştür (Okan-Andreev, 1961: 3).

Bu tarihlerde Bulgaristan'da bulunan Nazım Hikmet, Türk yönetiminin emperyalistlerin uşağı olduğunu belirtmiştir (Nazım Hikmet, 1952: 4). Türkiye'ye 1950-51 göçünün yaşandığı günlerdi. Nazım Hikmet “Sakın Türkiye'ye gitmeyin! İnsanlar orada ot yiyor.” diyerek göçü önlemeye çalışmıştır (Tata, 1993: 6). Mülteci Türk Osman Rauf Alper de Türkiye'de insanların mağaralarda yaşadığını anlatmaktadır. Elleri nasır tutmuş halk sömürülmektedir. Ancak emekçilerin zafere ulaşacağını söylemektedir (Alper, 1952: 4). Yine, Mağara Insanları başlıklı bir yazıda, Yaşar Kemal'in Bu Diyar Baştan Başa adlı eserinden alıntılar yapılmış ve doktor, okul, eğitim bilmeyen Anadolu halkının zor şartlar altındaki mücadelesi tasvir edilmiştir (Kemal, 1980: 24, 25).

Türkiye'de okur-yazar oranı çok düşük, komünist ülkelerde ise çok yüksektir (Türkiye Gazetesi, 1954: 3). Türkiye'de 1959 yılı itibariyle 116 kazada ortaokul yoktur. 17 bin 500 köyün ilkokula ve 39 bin ilkokul öğretmenine ihtiyacı vardır (Okan-Andreev, 1961: 65). 2 milyon çocuk okula gidememektedir (Türkiye Basınından, 1957: 4 ). Okur-yazar oranı sosyalist ülkelerde yüzde 100, Türkiye'de ise yüzde 38'dir (Osmanoğlu, 1970: 9). Türkiye eğitimsiz halkı, siyasi çalkantılı yaşantısıyla sağ-sol çatışmalarının yoğun olduğu 1970-80 arasında her gün can kaybı yaşanılan bir ülkedir. BKP ise doğu bloku ülkelerinin komünist partileri ile birlikte Türkiye'deki sol örgütlere milyonlarca dolarlık destek sağlamaktadır. ${ }^{3}$

Ekonominin kötü ve eğitimin olmadığı Türkiye'de 1960'lı y1llarda elektrik yoktu. Şehirler jeneratörlerle aydınlanıyordu. Köylere elektrik ise 1970'lerde gelmeye başladı (Ortaylı-Küçükkaya, 2012: 187). Bulgaristan Türkleri, 1980 y1lında Türkiye'de, 40 bin köyün 23 bininin elektriksiz olduğu, 15 milyon kişinin elektriksiz yaşadığı (Türkiye'de 15, 1980: 5) haberlerini okuduklarında zihinlerinde acınacak bir Türkiye algısı oluşturuluyordu. Türkiye dünyanın en geri kalmış ülkelerindendi. 1960 yılına yaklaşırken Türkiye'de doktor sayısı 12 binin altındaydı. Doktor olmayan

\footnotetext{
2 “Türkiyenin” ve "Mali” gibi bazı kelimelerdeki yanlış yazılımlar imlâ hatası gibi görülebilir bunun sebebi kaynakların aynen yazılmasidır.

${ }^{3}$ Ayrıntılı bilgi için bkz. Musa Qasımlı, SSCB-Türkiye İlişkileri.
} 
kazalar vardı. Bulgaristan'da 705 kişiye, Türkiye'de 2 bin 158 kişiye bir doktor düşüyordu. Bulgaristan'da verem problemi halledilmiş Türkiye'de ise yılda 30 bine yakın kişi veremden ölüyordu (Atanasof, 1960: 3). ${ }^{4}$

1960’l1 yıllarda Türkiye'den Avrupa'ya çalışmaya giden işçiler de propaganda malzemesi olmuştur (Almanyada Türk, 1967: 3). Her çeşit işte çalışan Türklerin tuvalet temizlikçiliğinden şikâyetçi olması (Bir Dokun, 1974: 8, 9) haberi BKP tarafindan Işste Türkiye ve Türkler şeklinde yansıtılmıştır. Mülteci Türk Halis Okan'a göre Türkiye, Sovyetler Birliği ve halk demokrasisi (doğu bloku üyesi) olan ülkelerle ilişkilerini geliştirdiği takdirde ekonomik kalkınmasının önü açılacaktır (OkanAndreev, 1961: 85). Türkiye de yönetim emperyalist ve sömürgeci bir zihniyet taşımaktadır. Kurtuluşu ise sosyalizmle olacaktır. Bu bağlamda sosyalizmle refaha ve mutluluğa kavuşan Türk Coğrafyası'ndan verilen örneklerle propaganda yapılmaktadır. Amaç Türklerin asimile edilmesi veya göç ettirilmesidir.

\section{Türk Coğrafyası Propagandası}

BKP'nin propagandalarına baktığımızda Türkiye, ABD başta olmak üzere emperyalist ülkelerin kontrolünde, halkı sefalet içinde ve yoklukla mücadele etmektedir. Kurtuluşu ise ancak sosyalizmle olacaktır. Türklere yönelik asimilasyon politikaları algı oyunlarıyla hayata geçirilmektedir. Bunlardan biri de Türk Coğrafyası'nın sosyalizm sayesinde ulaştığı mutlu ve müreffeh yaşantıdır. Türkiye dışındaki Orta Asya, Kafkasya, Kırım ve Balkanlar'dan müteşekkil Türk Coğrafyası'nın nerdeyse tamamı sosyalizm çatısı altındadır. SSCB içinde özgür ve mutlu(!) bir hayatları vardır. Bulgaristan Türklerine yönelik olarak Türk Coğrafyası'nın her köşesinden gezi ve röportaj yayınları, araştırma ve inceleme yazıları göze çarpmaktadır. Bulgaristan Türklerinin Türkiye ile olan bağları koparılmak istenmektedir. Bu bağları tamamen koparmak için Sovyet Rusya'daki Türkler gibi Bulgaristan Türklerinin de Türkiye Türklerinden farklı idealler peşinde koşan bir topluluk olmaları istenmektedir. Aynı Sovyet Rusya'daki gibi komünist bir rejim ile Bulgarların içinde bulunan Türklerin kültürel olarak yok edilmesine çalışılmaktadır (BCA, 1946: 030-0-010-000-000-243-6466).

Propagandalarda eğitimin ağırlıklı olarak ele alındığı görülmektedir. Bulgaristan'ın da aralarında olduğu sosyalist ülkelerde okur-yazar oranının çok yüksek, Türkiye'de ise çok düşük olması propagandacıların dayanak noktalarını güçlendirmekte ve haklı bir savunma yaptırmaktadır. Yazılarda devamlı vurgulanan ise sosyalizm veya Sovyet Yönetimi öncesi ve sonras1 k1yaslamalarıdır.

Azerbaycan halkı Sovyetlerden önce kültürden habersiz bir hayat sürerken sosyalizm ile birlikte halk köylerdeki evlerinde kütüphanelerini süsleyen Azerbaycan ve Rus Edebiyatı'nın seçme eserlerini okuyabilmektedir (Bir Azerbaycan, 1948: 4). Kazakistan gezisini aktaran Zekeriya Sertel tiyatroyu bilmeyen Kazakların Ekim Devrimi'nden sonra ciddi bir yol kat ederek oyuncuların Avrupa seviyesinde olduğunu belirtmektedir. Kazak edebiyatının kurucusu sayılan edip ve filozof Abay'ın derebeylerine karşı mücadelesinin anlatıldığı oyunu izleyen Sertel, oyuncuların mükemmel olduklarını hayranlıkla anlatmaktadır (Sertel, 1954: 116).

Sovyet Rus kültürünün Türk Coğrafyası'nda etkili olması Rusların hâkimiyeti döneminde verilen eğitimin ve kurulan üniversitelerin sayesinde olmuştur. 1927 yılında kurulan Kazakistan Devlet Üniversitesi bu açıdan önemlidir. İlerleyen yıllarda gelişen ve farklı bölümler açılan üniversitenin öğrencilerinin yarısı Kazak gençleridir. Eğitim alan öğrenciler ve akademisyenler sosyalist halk ekonomisi ve kültürü üzerine çalışmalar yapmaktadır (Tacibayef, 1948: 4).

Zekeriya Sertel'in özel olarak yaptığg Sovyetler Birliği gezisinden edindiği bilgilere göre Kazakistan nüfusu 1953 yılı sonunda 7 milyondur. Ekim Devrimi öncesi yüzde 2 olan okur-yazar oranı şimdi yüzde 100'dür. 9 binden fazla okul, 20 yüksek eğitim kurumu vardır. Gelişmeler Rus halkı ve parti sayesinde olmuştur. Özbekistan'ı da gezen Sertel şehirlerde 10. sınıfa, köylerde ise 7. sınıfa kadar

\footnotetext{
${ }^{4}$ Ayrıca T.C. Sağlık Bakanlığı da 1960 yılında veremden ölüm oranının Türkiye'de 100 binde 52 olarak açıklamaktadır. http://www.saglik.gov.tr/TR/belge/1-40121/tarihce.html
} 
eğitimin mecbur olduğunu görmüştür. Okur-yazar olmayan kalmamıştır. Fakat Türkiye'de 44 bin köyün 30 bininde okul yoktur (Sertel, 1954: 52, 117).

Eğitimle sosyalizme kazandırılmaya çalışılan ve propagandist olarak kullanılan gençlere yönelik benzer düşünceler Bulgaristan'daki Türkler için de geçerlidir. Eğitimli Türk gençleri sosyalizm propagandalarında kullanılmaktadır. Öyle ki Sofya Üniversitesi Felsefe-Tarih Fakültesi'nde eğitim gören, Bulgaristan'daki mülteci Türklerle beraber faaliyetlerde bulunan İbrahim Yalımov, Türkçülük karşıtı yazılarıyla tanınmaktadır. BKP tarafından Türkiye Komünist Partisi (TKP)'de etkili bir göreve gelmesi istenmiştir. Orhan Yalım kod adını kullanıyordu. Moskova'ya özel eğitim için gönderildi (Alper, 1999: 322).

Eğitimde dilin ayrı bir önemi vardı. BKP'nin talimatıyla yayınlarda Türkçe yerine Bulgarca ön plana çıkarılmaya başlandı. Türk çocukları, Bulgarca bilmiyorlar bu yüzden Bulgar çocuklarıyla oynayamıyordu. Sosyal yönleri zayıf kalıyordu. Çocuklar Bulgarcayı iyi öğrenip yüksek tahsil yaparak vatana hizmet etmeyi hayal ediyordu (Bulgarca, 1955: 1). BKP Sekreteri Todor Jivkov "Türkler eskiden olduğu gibi kendi dillerini kullanacak, eserlerini Türkçe verecek ve Türkçe müzik seslendirecek." demişti. Fakat Türkçe adına ne varsa yok edilmeye başlandı. Sosyalizm Türklere cehennem olmuştu (Şerefli, 1990: 138). Adını Mihail Yançev olarak değiştiren Muhiddin Mehmedov 1970’lerde Türkçe bir sözlük hazırladı. Sözlükteki Bulgarca kelimeler Türkçe kelimelerden daha fazlaydı (Cambazov, 2011: 204 ).

Sovyetler Birliği'nde de Rusça bütün halkların ikinci dili kabul edilmiştir. Propaganda yayınlarında, literatürde, mesela Tatarca sözlüklerde Tatarca kelimeler yerine Rusça kelimelere yer verilmektedir. 1955-58 y1llarında Kazan'da yayınlanan Rusça-Tatarca sözlükte 1929 yılına göre iki misli Rusça kelime vardı (Devletşin, 1981: 497). Model alınan Sovyetler Birliği uygulama alanı ise yok edilmek istenen Türklerdi. Gerçi Tatarlara okullarda Rusça öğretmek Sovyetlerin sömürgeci hâkimiyetiyle başlamamıştır. Bunu Sovyetler de icat etmemiştir. Ekim Devrimi'nden önce Tatar cedit okullarında Rusça dersleri kabul görmüştü. Tatarlar bugün bile Rus diline itiraz etmiyorlar. Ama Sovyet rejimi tarafından Rusça bir ders değil siyasi faktör olmuştur. Günümüzde ise Rusça, Tatarları ana dilindeki okullarından vazgeçirip Rus okullarına yönlendiren bir baskı unsurudur (Devletşin, 1981: 362).

Ekim Devrimi'nden önce Özbekler sömürge altındaydı. Derebeylikle yönetiliyordu. İnançları yüzünden Özbek kadını esaret hayatı yaşıyordu. Hurafeler kadınların sokağa çıkmasını engellemiş, eğitim aldırmamış, politika ve günlük faaliyetlerinden yoksun bırakmıştı. Stalin Anayasası sayesinde her alanda Özbek kadını vazife yapmaya başlamıştı. Sosyalizm özgürlük ve eğitim hakkı ile mükemmel bir hayat sunuyordu (İşantureva, 1948: 3).

Bulgaristan Türklerinin Türkiye ile bağlarını kopararak uzaklaştırılması hesap edilirken Türkçe ağızlarda ve kültürel anlamda en yakın Azerbaycan Türkleri olduğu düşünülerek Sovyet Azerbaycan'1 ile irtibata geçildi. Tabi ki Sovyet Rusya'nın izninin olmaması mümkün değildi. Özellikle dil ve eğitim alanında bir işbirliğine gidildi. Eğitim almak için ilk aşamada 13 erkek $2 \mathrm{k} 1 \mathrm{z}$ olmak üzere 15 Bulgaristan Türk genci 1952 y1lı başlarında Azerbaycan'a gitti. Bulgaristan Maarif Bakanı, Sovyetler Birliği'nden alınan ilimle Bulgaristan Türklerine fayda sağlanacağını açıkladı (15 Türk, 1952: 1).

Sosyalizm eğitim alanında en iyisini vermeye çalışıyor ve haklı bir övgüye layık görünüyordu. Moskova'da 37 tiyatro, 50 sinema 4 tane de çocuk tiyatrosu olduğunu söyleyen Sertel'i (Sertel, 1954: 7) doğrulayan Fethi Tevetoğlu, 1967 yılında Sovyetler Birliği’ne yaptığ 1 geziden şöyle bahsetmiştir; Bakü'de 1945 yılında kurulan Petrol Enstitüsü ve Fakültesinin önemli bir işlevi vardır. Azerbaycan'da 12 yüksekokulda çeşitli alanlarda binlerce uzman yetiştirilmektedir. 400 kadar akademik alanda doktora yapmış bilim adamı, ayrıca yaklaşık olarak 3 bin 500 tıp doktoru adayı vardır. 4 milyon 800 bin nüfusun yüzde 25'i ilköğretimden yükseköğretime kadar değişik mertebelerde öğrencidir. Okur-yazar oranı yüzde 100'dür. Kı̈ öğrencilerin okuma oranı da oldukça fazladır. Parasız ve mecburi olan orta öğretim sisteminde okullar gibi en ücra yerlerde binlerce kütüphane de vardır. Ayrıca sinema, tiyatro, kulüp, kültür sarayları ve devlet tekelindeki yüksek tirajlı 
basın ve yayın, radyo, televizyon şüphesiz birer propaganda aracıydı (Tevetoğlu, 1968: 186, 188). Bu propagandalar vasitasıyla sosyalizm adı altında yok edilmek istenen mazlumlar vardı.

Eğitimle birlikte Türk Cŏgrafyası'nda yaşayan kanaat önderleri de sosyalizmin propaganda unsuru olarak kullanılmaktadır. Kazakistan' da varlıklı insanlara karşı gelen, ağalığa kin tutan ve bu hislerini çocukluktan beri şarkılarda yaşatan, halkın içinden çıkan şair Cambul Cabayef burjuvaziye karş1 gerçekleri savunan biri olarak Bulgaristan Türklerine tanıtılmaktadır. Cabayef' in düşünceleri Ekim Devrimi ile 1917 yılında hayat bulmuştu. Stalin onu ödüllendirdi. Edebiyat dünyasında eserleriyle iftihar edilmeye başlandı (Fetoğlu, 1949: 4).

Sovyet Azerbaycan'1, propagandalarda özel bir yere sahiptir. Yayınlarda da s1k sık görülmektedir. Azerbaycan ve Bulgaristan arasında karşılıklı ziyaretler yapılmaktadır. Bu ziyaretlerin birinde Azerbaycan Türk'ü şair Samet Vurgun Bulgaristan Türklerine sosyalizm sayesinde Sovyet Azerbaycan'ının ilerleme kaydettiğini anlatmıştır. Halkın teknolojiyle donatılmış geniş evlere sahip olduğunu, makineli tarımla ülke ekonomisinin geliştiğini dillendirmiştir. Bu arada Türkiye' de yokluk içindeki halkın baskı gördüğü de hatırlatılarak Bulgaristan'da Türklerin şanslı olduğu vurgulanmıştır (Büyük Azerbaycan, 1951: 1). Yine bir başka yazıda Lenin ve Stalin'e övgülerin olduğu Azerbaycanlı şair Resul Rıza'nın şiirleri örnek gösterilerek sosyalizmle gelen mutluluklar aktarılmıştır (Riza, 1949: 4).

Sovyetler Birliği Arap ülkeleri ve Afrika ülkeleri ile ilişkilerini geliştirme ve bu coğrafyalarla doğu bloku ülkelerinin irtibata geçmesini teşvik etmektedir. Abdullatif Benderoğlu, Irak Türkmeni bir şairdir. Bulgaristan'a 1960'l y yllarda çeşitli sebeplerle ziyaretleri olmuştur. Resmi görüşmelerde de bulunan Benderoğlu, sosyalizmin Bulgaristan'ı nasıl kalkındırdığını anlatırken devrimci bir yönetimin geldiği Irak ile Bulgaristan arasındaki ilişkilerin sosyalizm sayesinde geliştiğini ve Bulgaristan'a hayranlığını ifade etmiştir (Benderoğlu, 1975: 20).

Bulgaristan Türkleri Türk Coğrafyası'nın dönem itibariyle tanınmış simalarının dilinden sosyalizme kazandırılmaya çalışılmaktadır. Dağıstan'dan Süleyman Stalski de bu simalardan biridir. Çocukluluğundan beri Semerkant ve Bakü'de ağır işlerde çalışmış ve hayatı sefalet içinde geçmiştir. Sovyetlerin hâkimiyeti öncesi ağır şartların olduğu coğrafyasında Ekim Devrimi ile güneş doğmuş ve Dağıstan aydınlanmıştır. Yazdığı şiirlerin sözlerini sazıyla müziğe döken halk şairi Stalski, Lenin ve Stalin'e hasrettiği şiirleriyle de sosyalizmin sağladığı refahı yazılarına dökmüştür. Eserleri SSCB edebiyatına girmiştir (Dağıstan, 1948: 4).

Bulgaristan'da Türk Coğrafyası'ndan mutluluk tabloları çizerek verilen mesajlarda bu bölgelerden gerçek haber alamayan Bulgaristan Türkleri umutsuz bir şekilde baskıcı rejimin işkencelerine maruz kalmaktadır. Bu mazlumlardan Ahmet Şerif Şerefli de yıllarca hapis yatmış işkence görmüştür. Cezasını çektiği Sofya'da 1976 yılında bir başka mahkûm mülteci Türklerden Halis Okan ile karşılaşır ve tanımadığı bu kişi kendisine gizlice bir gazete parçası verir. Gazete parçasındaki haber; Sovyetler Birliği'nde rejimi yıkmak isteyen Kırım Türk'ü Mustafa Cemil Kırımoğlu ve arkadaşlarının ölümle yargılanmasıdır. İlk defa duyduğu bu isim Şerefli’nin Türk Coğrafyası'nın farklı bölgelerinde dikta rejimlere karşı gelen soydaşların varlığından haberdar olmasını sağlamıştır. Bu duygu ve düşünceyle yok olan umutları tekrar yeşermiştir (Şerefli, 2005: 217).

Doğu bloku ülkeleri teknolojik gelişmişliğini de sergilemektedir. Moskova ve Bakü metroları Sovyetlerin yeraltı ulaşım faaliyetlerinde Avrupa ve Amerika'dan geri olmadıklarını göstermektedir (Tevetoğlu, 1968: 203). Sovyetler Birliği'nin desteği ile doğu bloku ülkelerinde üretim ekonomisi de canlanmıştır. Kendi aralarında oluşturulan pazar, makineli tarım, yeraltı ve yerüstü coğrafi zenginlik, ulaşım ağlarının geniş alanlara ve uç noktalara yayılması kuşkusuz bu canlılığa katkı sağlamıştır. Ancak halkların eşitliği sağlanmış ve doğu bloku insanları mutlu olabilmiş midir?

Orta Asya bozkırlarında zengin krom, kömür, bakır ve petrol yatakları olan Kazakistan, SSCB'nin büyük bir ülkesidir. Bu da Kazakistan’ı sanayi ülkesi yapmıştır. Kazakistan ve başkenti Almaata sosyalizmle birlikte değişmiş ve gelişmiştir. Uçsuz bucaksız toprakları modern sulama teknolojisiyle tarımda önemli bir yere gelmiştir (Sertel, 1954: 113). Doğa şartlarının hayatta kalmayı zorlaştırdığ bu bölgelere Sovyetlerin sosyalizm anlayışıyla hizmet götürdüğ̈ anlatılmaktadır. Susuz, yolsuz, ıssız 
Hazar havzasının önemli bir petrol bölgesi olan Mangışlak'ta kurulan tesislerde üretim 5 katına çıkarılmıştır. Sovyetlerin farklı bölgelerinden buraya gelen binlerce işçinin emeği ile yeşillendirilen bölgede kurulan şehirler bir emeğin karşılığıdır (Kazakistan, 1971: 7).

Tevetoğlu'da Azerbaycan'da denizden petrol çıkarmak için inşa edilen platformların görülmeye değer olduğunu belirtmektedir. Bakü'ye $33 \mathrm{~km}$ uzaklıkta Sumgait adlı yeni bir şehir inşa edilmiştir. Kimya ve metalürji sanayisinin en önemli merkezlerinden ve Rusların övündükleri bir yerdir. Geniş yolları, yeni binaları ve modern ulaşım araçları ile donatılmış bu şehirde nüfusun nerdeyse tamamı Ruslardan oluşmaktadır (Tevetoğlu, 1968: 178).

Türk Coğrafyası'nın modern ekonomiye sahip oldukları propagandaları Sovyetler'de de yapılmaktadır. Bu propagandalarda SSCB'yi ziyaret eden yabancı heyetler belli bölgelerde gezdirilerek sosyalizmin iyi yüzü gösterilmeye çalışılmıştır. Propagandalarda Orta Asya ve kısmen Azerbaycan'ın feodalizmden direk sosyalizme geçmesi minnetle hatırlatılmıştır. Günümüzde ise Türk Coğrafyası sakinleri bunu kabullenmemektedir. Gerçekte Türk Coğrafyası vahşice sömürülmüştür. Mesela 1922-1981 y1lları arasında Sovyetler'de sanayi üretimi 514 defa, Sovyet Azerbaycan'1nda ise 138 defa artmıştır. Sovyet döneminde Bakü'de 1 milyar ton petrol üretilmişti, gelirleri ise doğrudan Sovyet bütçesine bağlanmıştı (Nesibli, 2018: 207). Bulgaristan Türklerine aktarılan propagandalarda SBKP ağır sanayi kurmuş ve kısa zamanda da sonuçlarını görmüştür. Emekçilerin maddi refahını artırmak için de askeriyeye ayrılan bütçenin azaltılması ve barış yanlısı Sovyet halkının amacı doğrultusunda hareket edilmektedir. Sovyetlerin yükselişini hiçbir güç engelleyemeyecektir. Sovyet halklarının geleceği ümit değil hakikattir. Bulgaristan' da bu yolda ilerlemektedir (Daskalof, 1954: 9).

Sosyalizmin mutluluk resimleri gösterilmektedir. Coğrafya, ekonomi, endüstri ve tarım ile ilgili bilgilerin verildiği Bulgaristan Türklerine yönelik bir başka propaganda yazısında Azerbaycan'ın sosyalizm sayesinde geliştiği belirtilmiştir. Bu görüntünün Türkiye ve İran halklarına bir çağrı niteliği taşıdığı ve inkişaf etmeleri için komünizme yönelmeleri tavsiye edilmiştir (Penkof, 1954: 5). Azerbaycan'da köylünün geçmişi verimsiz arazilerde tahta sabanla geçim kaygısıydı. Sovyetler sayesinde makineli tarıma geçmiş, yüksek eğitimli uzmanların desteğinde mahsulleri birkaç kat artmıştır. Bu mutluluk Stalin'e gönderilen bir mektupla ifade edilmiştir (Azerbaycan Sovyet, 1948: 4). Mutluluk haberleri topraklarından bereket fışkıran, sosyalizme ve Sovyetlere minnet duyan Tacikistan köylülerinden de gelmektedir (S. S. Cumhuriyeti, 1948: 1). Rus halkının kardeş yardımı ile Sovyet Tacikistan'1 Ekim Devrimi öncesindeki yokluktan, cahillikten kurtulmuştur. İlim ve irfan yolunda büyük aşamalar kat eden Tacikistan'da sosyalizm sayesinde kültür merkezleri yapılmıştır (Hasanof, 1957: 4).

Bu minnet duyguları o kadar abartılarak ve gündemde tutularak verilmektedir ki Türkmenler de Türk Coğrafyası'ndaki yönetici Ruslara ve Sovyet vatanına olan derin sevgilerini belirtmektedirler. Vatan kelimesi Sovyet vatanı ile eş değerde tutulmaktadır. Çünkü Ekim Devrimi öncesinde Türkmenler padişah ve beylerin kölesiydi. Devrimle birlikte kölelik dönemi de bitmiş ve Türkmenler mutluluğa kavuşmuştur. Türkmenistan' da eğitim, teknoloji ve makineli tarım sosyalizm ile gelişti. Türkmenler bu hizmetleri Lenin-Stalin partisine borçluydu. Yönetici ve dost Rusların içten yardımları sayesinde bugünlere gelinmişti (Karayef, 1948: 3). Rusya'nın en geri kalmış topraklarından biri olan Türkmenistan'da müstakil üniversiteler olacağı hayal bile edilemiyordu. Okur-yazar oranının yüzde 1 bile olmadığı bir yerdi. Karanlık günler geride kaldı ve Stalin anayasası Türkmen halkını bir güneş gibi aydınlatt1 (Azimof, 1951: 1).

Tevetoğlu'nun Sovyetler Birliği izlenimine göre sosyalist rejim eşitlik adı altında gelirlerin büyük bir kısmını bütün gücü elinde tutan küçük bir azınlık grubuna kendi çıkarları için kullanma imkânı vermiştir. Sosyalist ideolojinin kalemşorlarının savundukları rejimin merkezinde mutlu azınlık vardı. Gözle görülür bir gelişme kaydettiği bir gerçek olan Sovyet Rusya, emperyalizm ve Amerika düşmanıdır. Sovyet Rusya'da yiyecek ve giyecek kalitesi hem çok düşük hem de çok pahalı idi. Halkın büyük çoğunluğu vakitlerini alışveriş kuyruklarında harcamak zorunda kalıyordu. Aslında kuyruk olmadan yapılan alışveriş yerleri de vardı ama fiyatlar birkaç kat daha pahalı, bazen de Amerikan doları ile yapılıyordu. İşte Sovyet Rusya'daki sosyal adalet! buydu (Tevetoğlu, 1968: 59, 
107). Ancak BKP yayınlarında Bulgaristan Türklerine aktarılan bilgiler de Moskova'da insanlar batılı ülkeler ve İstanbul'daki gibi perişan halde değildir. Her türlü yiyecek, içecek ve giyimin olduğu mağazalarda istediği şekilde alışveriş yapmaktadır (Sertel, 1954: 7).

Sovyet Rusya ile birlikte Türk Coğrafyası kalkınmış, refah seviyesi yükselmiştir. Sıkıntılar artık geçmişte kalmıştır propagandaları ile eğitim, tarım ve sanayi sosyalizm sayesinde zirvededir. Orta Asya bozkırları sanayi merkezlerine dönüşmektedir (Dünyada İlk, 1949: 2). Büyük Türkmen kanalının açılması uykudaki Orta Asya steplerini uyandırarak Türkmen ve Kazak halklarını refaha ve mutluluğa kavuşturacaktır (Amanof, 1951: 4). Öte yandan 2. Dünya Savaşı sıralarında Rusya ve Ukrayna'dan Kazakistan'a ağır sanayi işletmeleri kaydırılmıştır. Açılan bazı fabrikalar ve boş tarlaları ekin tarlasına dönüştürme politikasıyla bölgeye dışarıdan getirilen göçmenlerle demografik yapı Kazaklar aleyhine bozulmaya başlamıştır (Kurmanbayeva, 2018: 465).

Evet, Ruslar bozkırları yeşillendirmiş ve üretimi artırmıştır. Ancak bütün bu faaliyetlerde ileriye dönük planlar yapılmıştı. 1954 yılında Bakir Topraklar projesi adı altında Rus ve diğer Slav kökenli göçmenler Kazakistan'ın kuzeyine yerleşmiş ve nüfus Kazakların aleyhine gelişmiştir. Demografik yapının bozulması hep Rusların lehine olmuştur (Türk-Satymova, 2018: 450). Ruslar bir yandan demografik yapıyı bozuyor, bir yandan Rusçayı resmi dil olmaya zorluyordu. Bunları yaparken de sosyalizm ve gelişmişlik adına yapıyordu.

Demografik yapının bozulduğu bölgelerde ortak dil problemiyle karşılaşılıyordu. Bu durum yönetim dilinin ortak dil olmasını gerektiriyordu. Sovyetler Birliği’nde Rusça bilenlerin idari kadrolara alınması kanunlaştırıldı. Alt kademeden üst kademelere kadar terfilere Rusça bilme ölçüsü getirildi (Mircahmetov, 2012: 135). Bulgaristan'da da Türkçe yok edilmekte ve Bulgarcaya ağırlık verilmektedir. Bulgarca bilmeyenlerin yükseköğretim ve iş bulma konusunda hiç şansları yoktu.

Türk Coğrafyası'ndaki gelişmeler Sovyetler ve sosyalizmin halklara bakışı olarak yansıtılıyordu. Diğer yandan eski Çin'de Müslümanlar baskı görüyordu, dinî özgürlükleri yoktu. Çin tarihinde görülmemiş bir olay yaşanmış ve Çin Komünist Partisi ile gerçekleşmiştir. Müslümanlar tam bağımsızlıklarına ve ulusal eşitlik haklarına komünizm sayesinde sahip olmuştur. Artık Çin'de de İslam dinine, Müslümanların gelenek ve göreneklerine saygı gösterilmeye başlanmıştır. Çin bile İslam'a sayg1 gösteren bir rejime geçmiştir (600 Milyon, 1955: 13, 14). K1saca anlatılmak istenen şuydu; Sosyalist rejimler işçi, köylü, emekçinin refahı ve şahsi mülkiyet sahibi olması için en ideal ekonomik, politik ve hukuki şartlara zemin hazırlıyordu (Sovyetler Birliği'nde, 1948: 3).

Bu arada Üçüncü Dünya ülkeleri Sovyetleri emperyalist bir devlet olarak değerlendiriyordu. Güney Asya ve Afrika ülkeleri Moskova merkezli bir ilişkiye uzak duruyordu. Bu anlamda Sovyet yönetimi bu ülkelerle ilişkilerini Müslüman-Türk sömürgeleri aracılığıyla kurmayı planlamıştı. 1957 yılında Kahire'de yapılan bir toplantıya Sovyet Delegasyonu, Özbekistan Sovyet Cumhuriyeti Yüksek Şûrası Başkanı Şaraf Raşidov başkanlığında katıldı. Üçüncü Dünya ülkeleriyle ilişki kurma başarılı olmuştu. Sovyet rejiminde dinî ve millî kimlik korunuyor, sosyal ve ekonomik gelişme gösteriliyor mesajı verilerek Orta Asya Modeli Kalkınma kavramı ortaya atıldı. Özbekistan ve Taşkent bir vitrin olarak sunularak örnek kolhoz ve sovhozlar yaratıldı. Müftülükler aktif hale getirildi. Müslüman ülke merkezlerinde göstermelik birer cami açıldı. Böylece yabancı misafirlere bu yerler gösterilmeye başlandı (Andican, 2009: 498). Bu propagandaları "SSCB' de din serbesttir. İsteyen ibadet eder ve camiye gider. Devlet yardım etmez ama engel de olmaz." diyen Zekeriya Sertel'in Taşkent gezisi notları da desteklemektedir (Sertel, 1954: 106).

Başbakan Süleyman Demirel 1967 yılındaki ziyaretinde çölün sulama ile dönüştürülerek milyonlarca dönümlük arazide modern tarzda pamuk üretimi yapılan Aral havzasını görünce Sovyet Rusya'y1 takdir etti. Fakat bütün Rusya'nın pamuğunun yüzde 80'ini üreten Taşkent'te, Özbeklerin oturdukları evler Anadolu'nun en geri kalmış kazalarından farksızdı. Kiev, Leningrad veya başka bir Rus şehri ile kıyaslanamayacak derecede bir kültür merkezi olan bu şehirde sonradan yerleşen Ruslar iyi mahallelerde apartman katlarında oturuyorlardı (Tevetoğlu, 1968: 114, 115, 126). Tevetoğlu'na karşılık Sertel'e göre Orta Asya denilince akla takkeli, sivri sakallı, cübbeli insanların olduğu geri kalmış bir yer akla gelirdi. Türkiye'de de Orta Asya'dan gelenler gazetelerde hacca giden Özbekler 
olarak haberlerde verilirdi. Sosyalizmle birlikte Orta Asya halkları son derece gelişmiş, Türkiye'de gazetelerde görülenlerden ve hayal edilenlerden çok farklıydı. Ekim Devrimi'nden önce Taşkent çamurdan evleri, tozlu ve dar sokaklarıyla, kanalizasyon sistemi olmayan, içme suyu bulunmayan ve bu yüzden hastalıkların kol gezdiği geri kalmış bir Asya şehriydi. Sosyalizmle birlikte Taşkent, geniş yollara, içme suyuna, kanalizasyon sistemine, elektriğe kavuşmuş ve kurulan fabrikalarla ağır sanayi merkezi yapılmıştır (Sertel, 1954: 41, 44).

Rus nüfusunun artması, Rusçanın resmi dil olması, Rus olmanın avantajları Türk Coğrafyası'nda her geçen gün kendini daha da hissettirdi. Sadece Kazakistan'da 1959 yılında Rusların oranı yüzde 42'ye yükselmişti. Bu oran 1926' da yüzde 20 idi. 1926 yılında Rus ve diğer Slavların toplamı 2 milyon kişi idi. 1970 yılında ise 6 milyon 500 bin olmuştur. Orta Asya da Rusların nüfusu 1989'a kadar artış göstermiş daha sonraki yıllarda da düşüşe geçmiştir. 1989 yılında yaklaş1k 10 milyon Rus nüfusunun olduğu Kazakistan, Kırgızistan, Tacikistan, Özbekistan ve Türkmenistan'da bugün Rus nüfusu yarı yarıya düşmüştür. Kalan nüfusun çoğu yaşlı ve önemli bir kesimi de etnik olarak karma ailelere mensup olanlardır. 2009 yılında Rus ve Slav oranı yüzde 23'lere kadar düşmüştür (Türk-Satymova, 2018: 451, 452). Tarımda üretimi artırmak adına Aral Havzası bugün doğal dengenin bozulması sonucu suları çekilmiş, çevresi çoraklaşmış bir vaziyette sosyalist dünyanın propagandasının acı bir gerçeği olarak karşımızdadır.

\section{SONUÇ}

Türkiye hariç Türk Coğrafyası'nda yaşayan Türklerin belirli dönemlerde yönetildikleri rejimler tarafından baskı, asimilasyon, zorunlu göç gibi kavramlara maruz kaldıkları gün gibi aşikârdır. Bulgaristan Türklerinin ele alındığı bu çalışmada SSCB sınırları içindeki Türk Coğrafyası'ndaki faaliyetler adı altında yapılan ve özellikle rejimin dayanak noktaları olarak eğitim başta olmak üzere, makineli tarım, sanayi, alt yapı, sağlık, kültürel hizmetler sürekli propaganda amaçlı gündemde tutulur. Propagandalarda Ekim Devrimi, sosyalizm ve Rus yönetimi öncesi ile sonrası, Bulgaristan'da da komünizm öncesi ve sonrası şeklinde karşılaştırmalar yapılır. Türkiye, ABD, emperyalizm ve sömürgecilik saflarında gösterilir. NATO üyesi olarak savaş yanlısıdır. Sağlık problemleri olan halkı eğitimsiz, yokluk ve sefalet içindedir. Mutsuzluk resimleri çizilir. Buna karşılık Sovyet Ruslar ve sosyalizm barışçı, emeğin karşılığını veren, önceki yönetimler tarafından asırlarca bölgelerinde hor görülen insanları mutluluğa, refaha, medeniyete kavuşturan kesimin temsilcisidir. Bulgaristan Türkleri de komünist parti sayesinde bu mutluluğu yakalamayı hak etmektedir. Bu çizgide yapılan propagandalarla Bulgaristan Türklerinin diline, dinine, geleneksel yaşantısına aşamalı olarak müdahale edilir ve komünizme kazandırma adı altında da Bulgar toplumu içinde asimile edilmeye çalışı1ır.

Türk Coğrafyası'nda Sovyet Rusların hizmetleri sanki karşılıksız yapılan ve komünist rejimin bir göreviymiş gibi verilir. Ancak döşenen demiryollarının, kurulan fabrikalarda üretilen mamullerin ve çıkarılan yeraltı zenginliklerin doğrudan merkezi yönetime ulaşması ve coğrafyanın kontrol edilmesi amacıyla yapıldığı anlaşılmaktadır. Üretim hırsıyla yapılan çalışmalarla Aral havzasının doğasının bozulması da ayrı bir trajedi olarak karşımıza çıkmaktadır. Türk Coğrafyası'ndaki demografik yapının aşamalı olarak Türkler aleyhine bozulması, Rusçanın resmi dil olması ve model alınan bu yaptırımların Bulgaristan Türklerine de benzer şekilde uygulandığı görülmektedir.

Bölge haritasındaki geniş coğrafyasıyla Kazakistan, güneyindeki Kırgızistan, Tacikistan, Özbekistan ve Türkmenistan'1 bir şemsiye veya kalkan gibi korumakta, adeta bir set görevi yapmaktadır. Özellikle Kazakistan'ın demografik yapısının bozulmasındaki amacın bu seti zayıflatmak ya da yıkmak olduğu düşünülebilir.

SSCB'deki halklar gibi Bulgaristan Türkleri de komünistlerin iktidarıyla birlikte halkların eşitliği ilkesi propagandası ile oyalandırılır. Bir toplumun ayakta kalmasının temel esaslarını teşkil eden dil, din, geleneksel yaşantı gibi haklar, rejimin propagandist ve kalemşorlarının telkinleriyle yok edilmeye çalışılır. Halkların eşitliğinde SSCB'de Ruslar, Bulgaristan'da Bulgarlar üstün halk olarak görülmektedir. Çeşitli politikalar ve propagandalara rağmen yok edilemeyen ve boyun eğmeyen 
Bulgaristan Türkleri 1989 baharında zemheri kışı yaşar ve yüz binlercesi Türkiye'ye göç ettirilir. Nitekim bütün bu propagandalar Bulgaristan başta olmak üzere Balkanlar, Orta Asya kısaca Türk Coğrafyası'nda tam anlamıyla başarılı olamamış fakat derin yaralar açmıştır.

Bugün Türk Coğrafyası'ndaki bağımsız Türk devletleri her alanda ilerlemelerini katlayarak sürdürmektedir. Bulgaristan Türkleri de 1989 yılı sonundan itibaren çok partili demokrasi dönemiyle birlikte kurulan hükümetlerde bakan, milletvekili, vali, belediye başkanı ve bürokrasinin farklı alanlarında hak ettikleri makamlara gelmektedir. Serbest iş gücüyle de hem Bulgaristan devleti hem de kendileri adına ciddi kazançlar sağlamaktadır.

\section{KAYNAKÇA}

15 Türk genci Azerbaycan'a okumağa gitti. (1952, 28 Şubat). Yeni Işık Gazetesi. 600 Milyon İnsanın Yaşadığı Hür Diyar. (1955). Yeni Hayat Dergisi. (1): 13, 14. Abdullatif Benderoğlu. (1975). Yeni Hayat-Nov Jivot Dergisi. (11): 20.

Akpınar, Mehmet ve Köksal, Süleyman (2016). Türkiyeli Komünistlerin Bulgaristan Türklerinin Dil ve Eğitimindeki Etkisi. Karadeniz Incelemeleri Dergisi. (21): 251-268.

Almanyada Türk işçilerinin yüzde 15’i işsiz kaldı. (1967, 16 Kasım). Yeni Işık Gazetesi.

Alper, Osman Rauf (1952, 14 Şubat). Bugünkü Türkiye’de mağra devri. Yeni Işık Gazetesi.

Alper, Osman Rauf (1999). Mülteci Komünist. 2. Baskı. İstanbul: Timaş Yayınları.

Amanof, A. (1951, Sayı 23). Karakum Çölünde yeni bir deniz yaratılıyor. Halk Gençliği Gazetesi.

Andican, A. Ahat (2009). Osmanlı'dan Günümüze Türkiye ve Orta Asya. İstanbul: Doğan Kitap.

Atanasof, H. (1960, 16 Ocak). Türkiyede sağlık işleri ne durumda? Yeni Işsık Gazetesi.

Azerbaycan Sovyet Sosyalist Cumhuriyetinde Köy Ekonomisinin Harp Sonrası İnkişafı. (1948, 1 Mayı). Yeni Işık Gazetesi.

Azimof, P. (1951, 9 Ocak). Aydın Yol. Halk Gençliği Gazetesi.

BCA, 30-10-0-0_241-627-19_, (24.4.1933).

BCA, 030-0-010-000-000-243-646-6, (1.8.946).

Bilalof, Selim (1959, 20 Ağustos). Dindarlık Belasından Nasıl Kurtulabildim? Yeni Işık Gazetesi.

Bir Azerbaycan Kolhozunda. (1948, 15 Ocak). Yeni Işılk Gazetesi.

Bir Dokun Bin Ah Dinle. (1974). Yeni Hayat-Nov Jivot Dergisi. (3): 8, 9.

Bulgarca ikinci Ana Dilimdir. (1955, 20 Mayıs). Halk Gençliği Gazetesi.

Bulgaristan Halk Cumhuriyeti Dışişleri Bakanlığının Türkiye Hükümetine Notası. (1952, 28 Şubat). Yeni Iş̧ı Gazetesi.

Bulgaristan Komunist Partiyasının Kurucusu ve Önderi. (1956, 14 Haziran). Yeni Işık Gazetesi.

Büyük Azerbaycan Şairi Samet Vurgun Halkımız Arasında. (1951, 30 Eylül). Yeni Işık Gazetesi.

Cambazov, İsmail (2005). Medresetü’n Nüvvâb Anılar-Belgeler. Sofya: Ahmed Davudoğlu Dostluk ve Kardeşlik Vakfı.

Cambazov, İsmail (2011). Bulgaristan Türk Basını Tarihinde, Yeni Işık-Nova Svetlina Gazetesi. İstanbul: Erkam Matbaası.

Cicovska, Vesela (1976). Bulgaristan'ın Kültürel Gelişimi (1944-1958). Hüsnü Yılmaz (Çev.). Bulgaristan'da Kapitalizmden Sosyalizme Geçiş Sorunlart: İçinde 247-284. İstanbul: Bilim. 
Dağıstan Halk Şairi Süleyman Stalski. (1948, 21 Kasım). Yeni Işsk Gazetesi.

Daskalof, G. (1954). Mesut Diyar. Yeni Hayat Dergisi. (1): 9.

Devletşin, Tamurbek (1981). Sovyet Tataristan’ı. Mehmet Emircan (Çev.). Ankara: Kültür Bakanlığı.

Dün Fereceli Bugün Brigadir. (1961, 14 Nisan). Halk Gençliği Gazetesi.

Dünyada ilk sosyalist memleketi olan Sovyetler Birliğinde hayat. (1949, 1 Mayıs). Yeni Işık Gazetesi.

Fetoğlu, Mehmet (1949, 7 Mart). Kazahistan Büyük Halk Şairi Cambul Cabayef. Yeni Işık Gazetesi.

Gürün, Kamuran (1983). Dış İlişkiler ve Türk Politikası (1939'dan Günümüze Kadar). Ankara: Ankara Üniversitesi Siyasal Bilgiler Fakültesi Yayınları.

Hasanof, K. (1957, 12 Aralık). Tacikistan Kültürü Görülmedik bir hızla gelişiyor. Halk Gençliği Gazetesi.

İşanturaeva, Sara (1948, 12 Aralık). Ben mesut, hür Özbek kadınıyım. Yeni Işık Gazetesi.

Karayef, Cuma Durda (1948, 26 Ekim). Türkmenistan Diyarı da Saadet ve Refaha Kavuştu. Yeni Işık Gazetesi.

Kazakistan Nefti. (1971, 23 Ocak). Yeni Işsk Gazetesi.

Kemal, Yaşar (1980). Mağara İnsanları. Yeni Hayat-Nov Jivot Dergisi. (12): 24, 25.

Kore Halkına Yardım Edelim. (1952, 29 Ocak). Halk Gençliği Gazetesi.

Kurban Bayramınız Kutlu Olsun!. (1947, 25 Ekim). Işık Gazetesi.

Kurmanbayeva, Şınar (2018). Sovyet Yönetimi Yıllarındaki Kazakistan'daki Dil Politikası. Yunus Koç ve Mikail Cengiz (Editörler). 100. Yılında Sovyet İhtilali ve Türk Dünyası. İçinde 464-466. Ankara: Hacettepe Üniversitesi Türkiyat Araştırmaları Enstitüsü Yayınları.

Mateev, Boris (1976). 9 Eylül 1944 Silahlı Halk Ayaklanmasının Önkoşulları, Etkenleri ve Zaferi. Hüsnü Yılmaz (Çev.). Bulgaristan'da Kapitalizmden Sosyalizme Geçiş Sorunlart: İçinde 9-46. İstanbul: Bilim.

Mircahmetov, Mekemtas (2012). Kazaklar Nasıl Ruslaştırılmaya Çalışıldı. Çankırı: Çankırı Karatekin Üniversitesi Avrasya Stratejik Uygulama ve Araştırma Merkezi Avrasya Araştırma Serisi4.

Nazım Hikmet'in Türk Halkına Hitabı. (1952, 13 Ocak). Yeni Işık Gazetesi.

Nesibli, Nesib (2018). Sovyet Rejimi ve Türklük: Eski Mirası Yeniden Değerlendirme. Yunus Koç ve Mikail Cengiz (Editörler). 100. Yllında Sovyet İhtilali ve Türk Dünyası. İçinde 203-210. Ankara: Hacettepe Üniversitesi Türkiyat Araştırmaları Enstitüsü Yayınları.

Okan, Halis ve Andreev, L (1961). Türkiye'de Emekçilerin Durumu. Sofya: Narodna Prosveta Devlet Neşriyatevi.

Ortayl1, İlber ve Küçükkaya, İsmail (2012). Cumhuriyet'in İlk Yüzyılı 1923-2023. İstanbul: Timaş Yayınlar1.

Osmanoğlu, İbrahim (1970). Türkiye’de Eğitimin Çıkmazları. Yeni Hayat Dergisi. (1): 9.

Partinin Kurucusu. (1976). Yeni Hayat-Nov Jivot Dergisi. (5): 1.

Penkof, İgnat (1954). Azerbaycan. Yeni Hayat Dergisi. (4): 5.

Petrof, P. (1955). Dinin Menşei. Yeni Hayat Dergisi. (7): 16, 17.

Qasımlı, Musa (2012). SSCB-Türkiye İlişkileri. İstanbul: Kaknüs yayınları.

Ramazan Bayramınız Kutlu Olsun!. (1948, 7 Ağustos). Yeni Işık Gazetesi.

Riza, Resul (1949, 11 Nisan). Azerbaycan. Yeni Işık Gazetesi. 
Saray, Mehmet (2000). Sovyet Tehdidi Karşısında Türkiye'nin NATO’ya Girişi III. Cumhurbaşkanı Celal Bayar'ın Hatıraları ve Belgeleri. 2. Baskı. Ankara: Atatürk Araştırma Merkezi.

Sertel, M. Zekeriya (1954). Sovyetler Birliğinde 45 Gün. Sofya: Narodna Prosveta Devlet Neşriyatevi.

Sovyet Hükümetinin Türkiye Hükümetine Notası. (1951, 11 Aralık). Halk Gençliği Gazetesi.

Sovyetler Birliğinde Şahsi Mülkiyet. (1948, 15 Eylül). Yeni Işık Gazetesi. s. 3.

S. S. Cumhuriyeti Tacikistanda. (1948, 21 Kasım). Yeni Işık Gazetesi.

Şerefli, Ahmet Şerif (1990). Türk Doğduk Türk Öldük. Ankara: Kültür Bakanlığı.

Şerefli, Ahmet Şerif (2005). Önce Düşünceler Kelepçelendi. II. Baskı. Ruse: Goren Dunav Vakfı.

Tacibayef, T. (1948, 14 Kasım). Kazahistan Devlet Üniversitesi. Yeni Işık Gazetesi.

Tata, Sabri (1993). Türk Komünistlerinin Bulgaristan Macerası. İstanbul: Boğaziçi Yayınları.

Tatarlı, İbrahim (2003). Bulgaristan'da Türk Halk Kültürü ve Edebiyatının Bazı Ana Sorunları, Türk Varlığı. Sofya.

Tatarlı, İbrahim (2009). Insan, Ulus ve Azınlıklar Hakları, Onların Yurtiçi ve Uluslararası Hukuksal Düzeni ve Bulgaristan'da Uygulanmalarının Sorunları. Sofya: ET Avrasya.

Tatarova, E. (1962, 18 Oktyabr). Domuz Bakıcı Halime Abla. Yeni Işık Gazetesi.

T.C. Sağlık Bakanlığg (2016). Tarihçe. http://www.saglik.gov.tr/TR/belge/1-40121/tarihce.html (7.3.2016).

Tevetoğlu, Fethi (1968). Benim Gördüğ̈̈m Bugünkü Rusya. Ankara: Komünizmle Mücadele Yayınları.

Todorova, S. vd. (Haz.) (2011). Bulgaristan Devrimci Gençlik Hareketi Tarihi. Orhan Aydın (Çev.). 2. Baskı. İstanbul: Evrensel Basım Yayın.

Türk, Fahri ve Satymova, Sabina (2018). Ekim Devrimi'nden Günümüze Orta Asya'da Rus Azınlığ1 ve Rusça: Kazakistan ve Tacikistan Örnekleri. Yunus Koç ve Mikail Cengiz (Editörler). 100. Yılında Sovyet Ihtilali ve Türk Dünyast: İçinde 449-456. Ankara: Hacettepe Üniversitesi Türkiyat Araştırmaları Enstitüsü Yayınları.

Türkiye Basınından. (1957, 28 Şubat). Halk Gençliği Gazetesi.

Türkiye'de 15 Milyon Kişi Elektriksiz. (1980, 3 April). Yeni Işık Gazetesi.

Türkiye Gazetesi Bulgaristanı Örnek Olarak Gösteriyor. (1954, 27 Ağustos). Halk Gençliği Gazetesi. Türkiyenin Askerileştirilmesi ve Askeri Masraflarının Artması. (1948, 19 Nisan). Yeni Işık Gazetesi. Türkiyenin Mali Durumu. (1948, 12 Aralık). Yeni Işık Gazetesi.

Vekov, Angel (1980). Seçkin Enternasyonalist. Yeni Hayat-Nov Jivot Dergisi. (10): 2, 3.

Yalımov, İbrahim (2000). 1876-1923 Dönemi’nde Türkiye’de Bulgar Azınlığı ve Sosyalist Hareketin Gelişmesi. Mete Tunçay ve Erik Jan Zürcher (Der.). Osmanlı Imparatorluğu'nda Sosyalizm ve Milliyetçilik (1876-1923): 2. Baskı içinde (133-162). İstanbul: İletişim Yayınları. 